\title{
Willingness to Pay for Species Conservation Programs: Implications for National Park Funding
}

\author{
Birgit Bednar-Friedl', Brigitte Gebetsroither² \& Michael Getzner ${ }^{3}$
}

Keywords: species conservation, willingness to pay, contingent valuation, management of protected areas, funding protected areas

\section{Abstract}

National park management increasingly considers voluntary contributions from visitors as potentially important sources of private funding for species conservation. We investigate visitors' willingness to pay (WTP) for the protection of two species differing in degree of endangerment and popularity (alpine ibex and rock partridge) in Austria's Hohe Tavern National Park. Our analysis reveals that visitors' attitudes towards and preferences for nature conservation in general determine the WTP and not so much the species' characteristics. The results suggest that conservation funding should be essentially public and only complemented by private funding because (i) potential (voluntary) contributions by visitors might not be sustainable in the long run, (ii) visitors' WTP mirrors preferences for nature conservation in general rather than for specific species conservation programs, (iii) the collection of private contributions by a new system might be complicated, and (iv) many protected areas lack the resources and capacities for marketing and branding which are essential prerequisites for attracting funds in the first place.
Profile

Protected area

Hohe Tavern National Park

Mountain range

Alps

Country

Austria

\section{Introduction}

A common and increasingly significant problem is funding national parks and their conservation programs for endangered species and ecosystems due to scarcity of public budgets and the political will to encourage complementary private funding of protected areas (WCPA 2000; Inamdar \& de Merode 1999; Getzner \& Müller 2008). A few contingent valuation studies have investigated whether national parks contribute to citizens' welfare and therefore justify governmental support (e.g. Lee \& Han 2002; Turpie 2003). The value of natural habitats and (recreational) benefits has been estimated for instance by Tsuge \& Washida (2003), Nunes (2002), Scarpa et al. (2000) and Getzner (2000), $)^{1,2}$ and has generally turned out to be significant compared to the costs of establishing and managing protected areas (PA). In the current study, we analyse visitors' attitudes and anticipated reactions towards two species conservation programs. The main purpose is to explore the visitors' willingness to pay (W'TP) for conservation policies for two species differing in likeability and endangerment and the socio-economic characteristics of visitors that may have a crucial influence on the stated willingness to contribute to species conservation.

These issues are accounted for in particular by testing the findings of e.g. Tisdell et al. (2004), who show that the WTP depends positively on the perceived endangerment of a species and not on its likeability or popularity, in contrast to earlier results, e.g. by Metrick and
Weitzman (1996), who identify the charisma of a species as the key determinant for species conservation expenditure.

Exploring the level and determinants of WTP for nature conservation programs is crucial for funding decisions of any PA management. First, WTP of visitors mirrors preferences

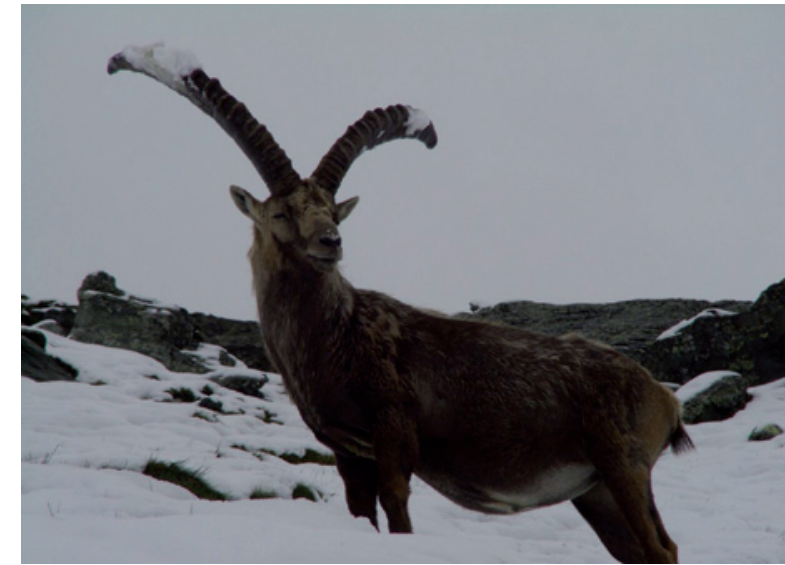

Alpine Ibex (C) Nationalpark Hohe Tauern/Mabler

for and benefits derived from such programs in money terms. Compared to the costs of such programs, a cost benefit analysis (CBA) may result in an economic measure of efficiency. Secondly, policy makers may base their decision about funding PAs on such studies since these might indicate an acceptance of charges and therefore could be used as a benchmark of public funding. Thirdly, private sponsors as well as PA managers receive information on the level of potential contributions (prices) which can be used to determine entry fees, prices of guided tours, merchandise and the scope of complimentary private funding of conservation. The level of WTP stated by visitors can only be used for such considerations - setting aside validity issues of the measurement concept and the survey - if visitors' WTP is stable over time and specific for certain 
species and facilities offered by the protected area. If, however, stated WTP in general mirrors preferences for species and eco-system conservation, the stated level of WTP does not yield reliable data for funding decisions in a specific PA.

The remainder of the paper is structured as follows. Section 2 gives a description of the survey design, the valuation objective and the sample. The mean willingness to pay for species conservation is derived in Section 3 and tested for differences between species, while the determinants of WTP are explored by means of standard regression models. In Section 4 we discuss the implications for park management, particularly for education and information policies, and for private funding of parks.

\section{A survey of visitor attitudes towards species conservation}

\section{Valuation object and sample}

A contingent valuation survey was carried out in the Hohe Tauern National Park, Austria, to investigate preferences for protecting two different local species. One sub-sample was asked to evaluate a conservation measure increasing the shy and hard-to-observe rock partridge population (Alectoris graeca saxatilis). The second sub-sample evaluated a policy which was said to stabilize the very popular, well-known alpine ibex population (Capra ibex). The ibex can be observed very easily due to its flight distance of only 20 metres (Lüps 1995). The survey was carried out by four interviewers at different sites in the park in July 2006. The total number of completed questionnaires was 440 . The response rate was close to $65 \%$.

The survey design

The questionnaire consisted of six sections concerning environmental attitudes in general, recreation activities in the park, travel costs and other expenses, the WTP for species conservation, the acceptance of and reaction to measures restricting visitor access, and some socio-economic characteristics of the respondents.

In order to explore the marginal willingness to pay for species conservation we used contingent valuation. Respondents were asked to value a management scenario for either the rock partridge or the alpine ibex which was described and visualized by means of information cards (for details see Behrens et al. 2006). As the elicitation format we used a double-bounded dichotomous choice format (see, e.g. Amirnejad et al. 2005). In particular, the respondents were asked hypothetically whether they would be willing to pay for a specific species conservation measure with five different initial bid values assigned randomly. Depending on the first answer (yes or no), either the next higher or the next lower bid level was asked in the follow-up question.

\section{Results}

Comparison of WTP measures for the rock partridge and the alpine ibex

Overall $35 \%$ of the respondents in the pooled sample (rock partridge and alpine ibex) report a positive WTP for the species conservation programs, corresponding to a Yes to the first and/or the second bid level offered to the respondent (see Table 2 for values).

Estimating the mean W'TP is more complex for dichotomous choice question formats than for openended ones and conditional on a priori distributional assumptions made (for details, see for instance Bateman et al. 2002; Haab \& McConnell 2003; Hutchinson et al. 2001). The values of the mean one-off WTP for an increase in the rock partridge population and maintenance of the alpine ibex population are given in Table 1. According to Bateman et al. (2002) and Carson et al. (2003), these estimates can be seen as the lower bounds of the true values. Mean WTP was about EUR 6.90 for the rock partridge, and EUR 8.70 for the ibex program. These figures are low, given WTP for species conservation programs in other protected areas. However, WTP cannot readily be compared across studies, since environmental valuation crucially depends on the context of valuation. For instance, Nunes et al. (2003) estimate up to EUR 120 for species conservation programs in their meta-analysis of existing WTP studies. The mean WTP for the protection of the alpine ibex is slightly higher than for the rock partridge, but this difference is only weakly significant at $\mathrm{p}=0.08$. Thus, in the following analysis we will pool the dataset for the rock partridge and alpine ibex and investigate the determinants for the stated WTP together, testing also for the significance of the species.

Discussion of the determinants of respondents' WTP for species conservation

The standard regression model estimates the probability that respondents answer Yes to the bid offered to them in the questionnaire (variable YES). All variables in the regression are explained in Table 2.

We estimate four different models that allow us to make specific conclusions about national park management and funding, ranging from a basic "individual" model to a broader model, taking into account also the social and political context of valuation.

Table $1-$ WTP for the rock partridge and alpine ibex

\begin{tabular}{|l|r|r|}
\hline & rock partridge & alpine ibex \\
\hline Mean WTP for the conservation measure [in EUR] & 6.89 & 8.69 \\
\hline Standard deviation & 0.79 & 0.89 \\
\hline Total sample size N & 211 & 170 \\
\hline Total (estimated) number of visitors per year to the respective habitat & 23000 & 800000 \\
\hline
\end{tabular}


Table 3 presents the estimation results for the four models differing in the number of included variables. First of all, the willingness to accept an offered bid (as measured by a Yes answer to the bids offered) is strongly and inversely related to the bid level (variable BID), as one would expect from economic theory. Another important result in accordance with most contingent valuation (CV) studies (e.g. Amirnejad et al. 2005; Carson 2003; Bandara \& Tisdell 2004) is the fact that income is positively related to the probability of accepting an offered bid.

Regarding the variable IMPORTANCE, our results show that if the respondents' self-assessment indicates that they hold strong preferences for nature conservation, the probability of accepting the offered bid increases.

The actual behaviour of visitors and their knowledge about the Hohe Tauern National Park and its conservation tasks is covered by the variable NP-CENTER. Very often respondents who are better informed about nature conservation and species conservation in the park are also willing to pay more for these benefits (e.g. Bandara \& Tisdell 2004; White et al. 2001).

The average time spent on travelling to the park is measured by the variable DUR-TRIP ( 6.8 hours on average). The variable is significant at the $5 \%$ level and has a negative sign, meaning that visitors who spent more time getting to the national park exhibit a lower WTP for nature protection measures.

Differences between visitors spending their whole vacation in the area versus visitors coming only for the day (variable DAY-VISITOR) are connected to the respondents' WTP. Those staying in the national park only for the day (44\% of the respondents) are less likely to accept an offered WTP bid.

To test whether the likeability and charisma of a species influences the WTP for it, we include the variable IBEX, which takes a value of one for the ibex scenario. While we find the probability of stating a positive
WTP to be higher for the charismatic ibex than for the partridge (indicated by a positive coefficient), this effect is insignificant (Model 1 of Table 3). Another major influence on respondents' WTP is the perception that nature conservation is a public

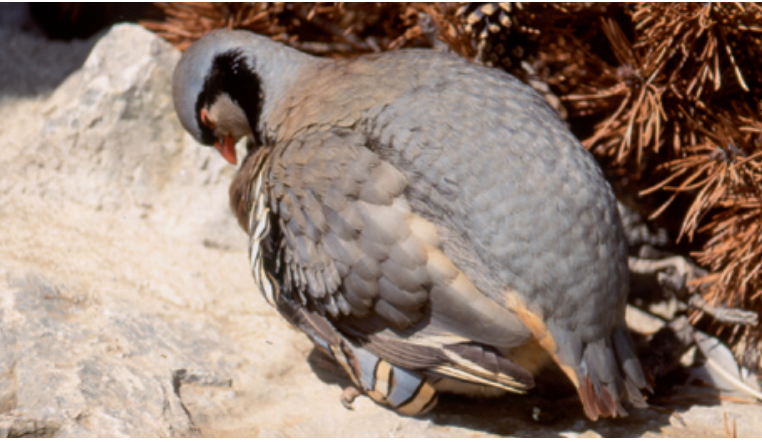

Rock Partridge (C) Nationalpark. Hohe Tauern/Lerch task (a perception held by $64 \%$ of respondents; see also Getzner 2005; Benett et al. 2003) or that species conservation should generally be funded publicly. The variable PUBLIC turns out to be highly significant at the $1 \%$ level, showing a smaller probability of respondents accepting the bids offered if they think that the public should pay for nature conservation (see Model 2 in Table 3).

Model 3 of Table 3 tests for the significance of the variable LOCALS. While the other coefficients stay within the same order of magnitude, the explanatory power is slightly improved.

Following a similar line of argument, the last model intends to account for additional arguments affecting the respondents' decision to state a certain WTP. The variable OTHERS denotes the willingness to contribute to species conservation even if other visitors would not be willing to pay. The variable may therefore be considered a measure for the strength of preferences for joint/social contributions. Model 4 in Table 3 predicts $85.78 \%$ of all answers correctly, which is higher than for all other models.

The results of the WTP survey suggest that stating a positive WTP not only depends on the respondents' socio-economic characteristics, national park experience and activities, but also on their perception of the political and social context (cf. Schläpfer

Table 2 - Variables for the econometric determination of respondents' positive bids

\begin{tabular}{|c|c|c|}
\hline Variable label & Description & Values \\
\hline \multicolumn{3}{|c|}{ Explanatory variables } \\
\hline BID & Bid offered to respondents in the valuation question & $\begin{array}{l}\text { BID = bid offered in EUR according to the bid vector } \\
\text { [EUR 5-10-15-20-25-30-35] }\end{array}$ \\
\hline DAY-VISITOR & Type of visitor (day trip vs. longer stay) & DAY-VISITOR = 1 for visitors staying only for the day \\
\hline DUR-TRIP & Travelling time from home to the park & DUR-TRIP = distance in hours \\
\hline IBEX & Dummy for scenario type (ibex vs. partridge) & $\mathrm{IBEX}=1$ for ibex questionnaire version \\
\hline IMPORTANCE & Preferences for conservation & $\begin{array}{c}\text { IMPORTANCE = } 1 \text { if respondents consider conservation to be "very } \\
\text { important" or "important" }\end{array}$ \\
\hline INCOME & Net monthly household income of the respondent & INCOME $=1$ if higher than EUR 2500 \\
\hline LOCALS & $\begin{array}{l}\text { Residence of respondents in order to differentiate between } \\
\text { tourists from outside the region and local residents }\end{array}$ & LOCALS $=1$ for local residents in the sample \\
\hline NP-CENTER & $\begin{array}{l}\text { Visit by the respondent to the national park centre } \\
\text { (exhibitions) }\end{array}$ & NP-CENTER $=1$ for respondents having visited the national park centre \\
\hline OTHERS & Importance of public funding & $\begin{array}{c}\text { OTHERS = } 1 \text { for agreement with the statement that if the respondent } \\
\text { would not pay individually, others would not be willing to pay individu- } \\
\text { ally either }\end{array}$ \\
\hline PUBLIC & Public responsibility for conservation & PUBLIC $=1$ if respondents state that conservation is a public task \\
\hline \multicolumn{3}{|c|}{ Dependent variable } \\
\hline YES & a Yes response to the bid offered & 1 for Yes respondents, 0 for others \\
\hline
\end{tabular}


2007). The study also highlights the importance of a broad range of determinants for WTP, which more or less limit the usability of WTP values as a basis for concrete information for funding policies of PAs.

\section{Conclusions for national park management and funding}

The current paper presents the results of a willingness-to-pay survey carried out in the Hohe Tauern National Park, Austria. While the survey reveals that visitors are willing to pay for species conservation in the park, management activities in the national park should not be oriented too closely to visitors' preferences and perceptions. As the example of the ibex illustrates, a prominent national park species (flagship species) might contribute only marginally to biodiversity conservation in alpine ecosystems. Rather, the ibex may serve as an example of species conservation which can be presented publicly with the aim of raising awareness for other non-prominent species and the need for their conservation in terms of integrative management of PAs. WTP for the ibex therefore could be high, but may not turn out to be sufficiently specific to mirror "true preferences" for species conservation.

This leads us to the question of whether there is a "fixed budget" corresponding to visitors' WTP for conservation programs in the Hohe Tauern National Park regardless of the specific program offered to visitors. An indication in favour of this claim is that the probability of accepting one of the offered bids is lower for the ibex than for the partridge (despite the higher mean WTP for the ibex), but the coefficient in our model estimations is not significant. We have two explanations for this result. Either the differences between conservation programs are not perceived as such, or respondents hold a general WTP for species and ecosystem conservation which can be interpreted as a "budget line" for voluntary contributions, regardless of the species in question. The task for national park management is thus to find out how to turn this generally positive attitude towards species conservation into actual private donations. More significant for PA management, however, is the conclusion that a potentially costly differentiation in terms of different species programs open for private contributions does not lead to a more efficient allocation of funds, since private donors apparently do not perceive programs differently.

In terms of financing conservation measures, the question arises as to what extent visitors should finance conservation programs while the general public enjoys the non-use values as well. First of all, a brief calculation reveals that private funding of conservation measures is generally not sufficient to finance the conservation measures needed for conserving biodiversity in the long term. Even if we assume that the maximum number of visitors (annually over 1 million in the Hohe Tauern National Park) might pay the average stated WTP of approx. EUR 8, it is questionable whether this (individual) WTP is sustainable and stable.

Secondly, the problem has to be solved of how the park management might collect such funds. In a recent study Getzner and Müller (2008) suggest that - instead of hoping for voluntary contributions and setting up a new system of fees - certain existing levies, such as the local tourist tax or the toll collected on park roads, should also include a "National Park cent". Such a surcharge system could be easily administered and might also be considered equivalent to charging users for park facilities.

Currently the Hohe Tauern National Park is funded by grants from the regional government and the Republic of Austria. Of course, complementary funding may include marketing local products related to the national park. Efficient and effective conservation policies

Table 3 - Determinants of respondents' willingness to pay for species conservation programs

\begin{tabular}{|c|c|c|c|c|c|c|c|c|}
\hline \multicolumn{9}{|c|}{ Dependent variable: YES } \\
\hline & \multicolumn{2}{|c|}{ Model 1} & \multicolumn{2}{|c|}{ Model 2} & \multicolumn{2}{|c|}{ Model 3} & \multicolumn{2}{|c|}{ Model 4} \\
\hline Variable & Coefficient & z-Statistic & Coefficient & z-Statistic & Coefficient & z-Statistic & Coefficient & z-Statistic \\
\hline BID & -0.042 & $-3.068^{* * *}$ & -0.032 & $-2.187^{* *}$ & -0.056 & $-4.250^{* * *}$ & -0.051 & $-2.264^{* *}$ \\
\hline INCOME & 0.435 & $1.676^{*}$ & 0.653 & $2.314^{* *}$ & 0.710 & $2.510^{* *}$ & 0.809 & $1.870^{*}$ \\
\hline IMPORTANCE & 0.391 & 1.501 & 0.761 & $2.627^{* * *}$ & 0.609 & $2.156^{* *}$ & 0.835 & $1.993^{* *}$ \\
\hline NP-CENTER & 0.329 & 1.118 & 0.513 & $1.586\left(^{*}\right)$ & 0.469 & 1.436 & 0.883 & 1.949* \\
\hline DUR-TRIP & -0.065 & $-2.299 * *$ & -0.063 & $-2.101^{* *}$ & & & & \\
\hline DAY-VISITOR & -0.606 & $-2.098^{* *}$ & -0.517 & $-1.653^{*}$ & -0.534 & $-1.718^{*}$ & -0.728 & $-1.588\left(^{*}\right)$ \\
\hline IBEX & 0.194 & 0.711 & 0.256 & 0.877 & 0.303 & 1.034 & -0.257 & -0.592 \\
\hline PUBLIC & & & -1.893 & $-5.658^{* * *}$ & -2.129 & $-6.180^{* * *}$ & \begin{tabular}{|l|}
-1.591 \\
\end{tabular} & $-3.488^{* * *}$ \\
\hline LOCALS & & & & & 1.100 & $2.702^{* * *}$ & 1.016 & $1.816^{*}$ \\
\hline OTHERS & & & & & & & -0.214 & $-1.721^{*}$ \\
\hline S.E. of regression & & 0.441 & & 0.412 & & 0.406 & & 0.340 \\
\hline Sum squared resid. & & 57.085 & & 49.692 & & 50.399 & & 23.436 \\
\hline Log likelihood & & -169.521 & & -149.341 & & -152.214 & & -76.828 \\
\hline$\%$ correctly predicted & & $72.67 \%$ & & $74.67 \%$ & & $75.40 \%$ & & $85.78 \%$ \\
\hline $\mathrm{n}$ & & 300 & & 300 & & 313 & & 313 \\
\hline
\end{tabular}

${ }^{* * *} p<0.01 ;{ }^{* *} p<0.05,{ }^{*} p<0.1$ 
are certainly at the heart of the park's "unique selling position". Therefore, fulfillment of the core functions of the park has to be secured - the respondents in our survey are generally aware that national park aims are public tasks. Only then will there be a sustainable and credible basis for private and public funding.

And thirdly, protected areas frequently lack the resources and the capacities for marketing and branding and for attracting substantial private funds. Thus the results of this study suggest that funding for the park's core activities should come from public sources. Private funding must therefore be considered predominantly as a complementary instrument.

Our results also show that concentrating on information regarding the conservation of endangered species should be an absolute priority for the national park management. The model estimates suggest that information and education about the park management, its facilities and nature conservation programs are important for park visitors' positive WTP for conservation. It is worth pointing out, however, that informing and educating visitors and the general public is clearly a long-term approach because preferences for species conservation expressed during brief visits to a national park have to be transformed into stable preferences. This is indicated by the survey since day visitors state a lower WTP than visitors who stay in the region much longer.

Summing up the often voiced call for extensive private funding of PAs is problematic since the results of the survey suggest that the (private) WTP of visitors might not be sustainable in the longer run. Moreover, WTP is not specific in terms for contributions to concrete conservation programs. It might also be complicated to set up a system of "skimming off" private WTP in a new system because of limited resources in protected areas for marketing, branding and attracting private funds for conservation. Finally, the majority of visitors perceive the funding of protected areas as a public task with only limited room for private contributions.

\section{Acknowledgements}

We would like to thank Dimitrios Manopoulos, Florian Spendlingwimmer and Birgit Wolkinger for their help in conducting the survey, the administration of the Hohe Tauern National Park for their support and their suggestions for designing the scenarios, and the Jubiläumsfonds der Österreichischen Nationalbank (project no. 11216) for financial support. We also gratefully acknowledge suggestions by participants at the 8th BIOECON conference in Cambridge/ UK, August 2006, at the 15th EAERE Conference in Thessaloniki/Greece, June 2007, and by an anonymous reviewer. All remaining errors are, of course, the responsibility of the authors.

\section{Endnotes}

${ }^{1}$ For instance, McMillan et al. (2002), White et al. (2001), Giraud et al. (2002); Nunes and van den Bergh (2003) and Christie et al. (2006) provide extensive overviews on species and ecosystem valuation.

${ }^{2}$ There are also numerous studies on the regional economic effects of PAs (e.g. Mose 2007; Getzner et al. 2008). However, results of these studies do not concentrate on visitors' W'TP for conservation but focus on the value added and on the employment effects from establishing and managing PAs.

\section{References}

Amirnejad, H., S. Khalilian, M. H. Assareh \& M. Ahmadian 2005. Estimating the existence value of north forests of Iran by using a contingent valuation method. Ecological Economics 58: 665-675.

An, M.Y. \& R.A. Ayala 1996. Nonparametric estimation of a survivor function with across-interval-censored data. Mimeograph, Durham: Economics Dept. Duke University.

Bandara, R. \& C. Tisdell 2004. The net benefit of saving the Asian elephant: a policy and contingent valuation study. Ecological Economics 48: 93-107.

Bateman, I., R. Carson, B. Day, M. Hanemann, N. Hanley, T. Hett, M. Joens-Lee, G. Loomis, S. Mourato, E. Özdemiroglu, D. Pearce, R. Sugden \& J. Swanson 2002. Economic valuation with stated preference techniques A Manual. Cheltenham.

Bateman, I.J., B.H. Day, S. Georgiou \& I. Lake 2006. The aggregation of environmental benefit values: welfare measures, distance decay and total WTP. Ecological Economics 60: 450-460.

Behrens, D., B. Friedl, B. Gebetsroither, M. Getzner \& S. Lieb 2006. Optimal dynamic nature conservation strategies. Mimeograph, Klagenfurt.

Bennett, R.M., R. B. Tranter \& R.J.P. Blaney 2003. The value of countryside access: a contingent valuation survey of visitors to the Ridgeway National Trail in the United Kingdom. Journal of Environmental Planning and Management 46, 5: 659-671.

BirdLife International 2004. Birds in Europe: population estimates, trends and conservation status. Birdlife Conservation Series, 12. Cambridge.

BirdLife International 2005. Species factsheet: Alectoris graeca. Available at: http://www.birdlife.org

Carson, R.T., R.C. Mitchell, M. Hanemann, R.J. Kopp, S. Presser \& P.A. Ruud 2003. Contingent valuation and lost passive use: damages from the Exxon Valdez Oil Spill. Environmental and Resource Economics 25: 257-286.

Christie, M., N. Hanley, J. Warren, K. Murphy, R. Wright \& T. Hyde 2006. Valuing the diversity of biodiversity. Ecological Economics 58: 304-317.

Getzner, M. 2000. Hypothetical and real economic commitments, and social status in valuing a species protection program. Journal of Environmental Planning and Management 43: 541-559. 
Getzner, M. 2005. A framework for valuing nature: regional biodiversity. In: Getzner M., C. Spash \& S. Stagl (eds.), New approaches to valuing nature. London.

Getzner, M. \& B. Müller 2008. Managing and financing a network of protected areas. Final report to the regional government of Carinthia, University of Klagenfurt.

Getzner, M., M. Jungmeier, B. Müller \& D. Zollner 2008. Case study report on the Hohe Tauern National Park (Austria). Dept. of Economics, Klagenfurt University. Research Report to Western Norway Research Institute. Sogndal, Norway.

Giraud, K., B. Turcin, J. Loomis \& J. Cooper 2002. Economic benefit of the protection program for the Steller sea lion. Marine Policy 26: 451-458.

Haab, T. \& K.E. McConnell 2003. Valuing Environmental and Natural Resources - The Econometrics of nonmarket valuation. Cheltenham.

Hanley, N., F. Schläpfer \& J. Spurgeon 2003. Aggregating the benefits of environmental improvements: distance decay functions for use and non-use values. Journal of Environmental Management 68: 297-304.

Hafner, F. 1994. Das Steinhubn in Kärnten: Ökologie, Verbalten und Lebensraum. Carinthia II Special Issue 52. Klagenfurt.

Hutchinson, W.G., R. Scarpa, S.M. Chilton \& T. McCallion 2001. Parametric and non-parametric Willingness to Pay for forest recreation in Northern Ireland: a discrete choice contingent valuation study with followups. Journal of Agricultural Economics 52, 1: 104-122.

Inamdar, A. \& E. de Merode 1999. Towards financial sustainability for protected areas.

Jakobsson, K.M. \& A.K. Dragun 1996. Contingent valuation and endangered species: Methodological issues and applications. Cheltenham.

Kotchen, M. J. \& S. D. Reiling 2000. Environmental attitudes, motivations, and contingent valuation of nonuse values: a case study involving endangered species. Ecological Economics, 32: 93-107.

Lee, Ch.-K. \& S.-Y. Han 2002. Estimating the use and preservation values of national parks' tourism resources using a contingent valuation method. Tourism Management 23: 531-540.

Lüps, P.1995. DerSteinbock. BündnerMonatsblatt.Chur. McMillan, D.C., L. Philip, N. Hanley \& B. AlvarezFarizo 2002. Valuing the non-market benefits of wild goose conservation; a comparison of interview and group-based approaches. EcologicalEconomics43, 1:49-59.

Metrick, A. \& M.L. Weitzman 1996. Patterns of behavior in endangered species preservation. Land Economics $72: 1-16$.

Mose, I. (ed.) 2007. Protected Areas and Regional Development in Europe: Towards a New Model for the $21^{\text {st }}$ Century. Aldershot.

Nunes, P. 2002. Measuring the economic benefits of protecting the Parque Natural do Sudoeste Alentejano e Costa Vicentina from commercial tourism development: results from a contingent valuation. Portuguese Economic Journal 1: 71-87.
Nunes, P., J. v.d. Bergh \& P. Nijkamp 2002. The Ecological Economics of Biodiversity. Cheltenham. Scarpa, R., S.M. Chilton, W.G. Hutchinson \& J. Buongiorno 2000. Valuing the recreational benefits from the creation of nature reserves in Irish forests. Ecological Economics 33: 237-250.

Schläpfer, F. 2007. Contingent valuation: a new perspective. Ecological Economics 64: 729-740.

Tisdell, C., H.S. Nantha \& C. Wilson 2006. Endangerment and likeability of wildlife species: How important are they for payments proposed for conservation? Ecological Economics 60: 627-633.

Tsuge, T. \& T. Washida 2003. Economic valuation of the Seto Inland Sea by using an Internet CV survey. Marine Pollution Bulletin 47, 1: 230-236.

Turpie, J.K. 2003. The existence value of biodiversity in South Africa: how interest, experience, knowledge, income and perceived level of threat influence local willingness to pay. Ecological Economics 46: 199-216.

WCPA 2000. Financing Protected Areas. World Commission on Protected Areas (WCPA). Best Practice Protected Area Guidelines Series No. 5. Gland, IUCN.

White, P.C.L., A.C. Bennett \& E.J.V. Hayes 2001. The use of willingness-to-pay approaches in mammal conservation. Mammal Review 31, 2: 151-167.

\section{Authors}

Birgit Bednar-Friedl

Assistant Professor at the Dept. of Economics; Vice-Head of the Economics of Climate and Global Change Research Group at the Wegener Center for Climate and Global Change, University of Graz. As an environmental and resource economist she models questions of conservation, climate change and trade.

${ }^{1}$ Department of Economics, University of Graz, Universitätsstraße 15, $8010 \mathrm{Graz}$, Austria

Birgit.Friedl@uni-graz.at

\section{Brigitte Gebetsroither}

Researcher at the Wegener Center for Climate and Global Change, University of Graz. She specializes in statistics and econometrics applied to environmental economics and transport policy.

${ }^{2}$ Wegener Center for Climate and Global Change, University of Graz, Leechgasse 25, 8010 Graz, Austria Brigitte.Gebetsroither@uni-graz.at

Michael Getzner, corresponding author Associate Professor of Economics, Dept. of Economics, University of Klagenfurt, Austria; director of the M.Sc. program "Management of Protected Areas". His main fields of research include environmental and ecological economics, public finance, infrastructure economics, cultural economics.

${ }^{3}$ Department of Economics, University of Klagenfurt, Universitaetsstraße. 65-67, 9020 Klagenfurt, Austria

Michael.Getzner@uni-klu.ac.at 